\title{
OCEAns Apart?: The Rule of Lenity in Australia AND THE UNITED STATES
}

\author{
Julian R Murphy*
}

\begin{abstract}
Occasionally traced back to Byzantine times, the rule that penal statutes are to be interpreted strictly in favor of the subject, also known as the rule of lenity, now finds expression in common law countries across the world. This Article compares the origins and evolution of the rule in Australia and the United States. The comparison is timely because of the current uncertainty in both jurisdictions about the rule's rationale and scope and because of an emerging global trend towards the "constitutionalization" of common law rules of interpretation. In the course of the analysis, various facets of the rule are discussed, including its common law origins; jurisprudential development; purported constitutional foundations; and modifications by state and federal statutes. Tracing the rule's development in each country reveals significant commonalities, but also important differences, in the respective approaches to the interpretation of criminal statutes. Most importantly, despite similarities in the two countries' constitutional structures, the rule has assumed constitutional significance in the United States but not in Australia. Identification of this marked difference provides an opportunity to reflect on the separation of powers, and the federal structure, of each country.
\end{abstract}

KEYWORDS

Legislation, Statutory Interpretation, Strict Interpretation, Lenity, Penal Laws

\section{CONTENTS}

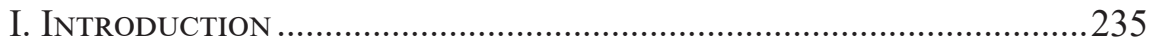

II. Some Terminological Ground-Clearing ...................................236

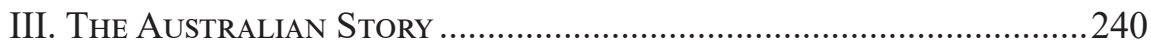

A. Early Case Law from the High Court ........................................240

B. Modern and Contemporary Case Law: The "Last Resort" Rule 243

C. A Constitutional Dimension? ..........................................................2 244

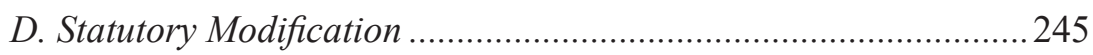

* PhD student, University of Melbourne, School of Law. Part of this Article was written during the course of a Human Rights Fellowship at Columbia Law School. I would like to thank Akhil Amar, Kent Greenawalt, Walter Loughlin and Judge Jed Rakoff for discussions about federalism, criminal law and lenity. All opinions and errors are my own. 
E. Summary of the Current Australian Approach .............................246

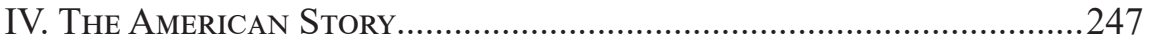

A. Early Case Law from the Supreme Court....................................247

B. Modern and Contemporary Case Law: The "Tiebreaker" Rule 248

C. Constitutional Foundations........................................................250

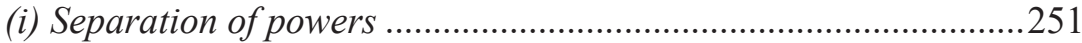

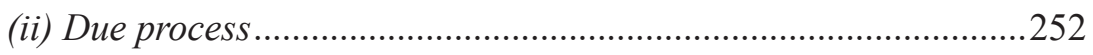

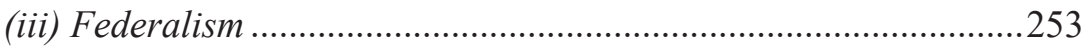

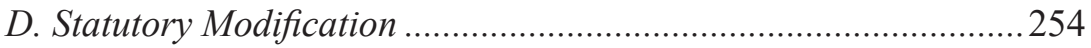

E. Summary of the Current American Approach ………………......256

V. Similarities, Differences and Attempts at Explanation................257

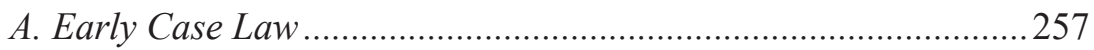

B. Constitutional Foundations.........................................................258

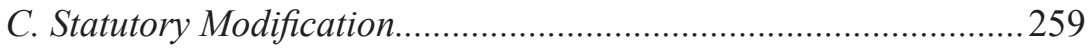

D. Contemporary Iterations of the Rule ..........................................259

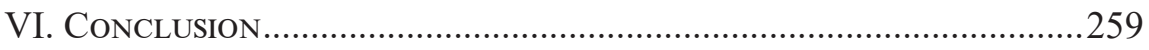




\section{INTRODUCTION}

The rule that penal statutes are to be interpreted strictly, also known as the rule of lenity ("the rule"), has been said to be as old as the task of statutory interpretation itself. ${ }^{1}$ It has also been labelled "the subject of more constant controversy than perhaps of any in the whole circle of the Law."2 All agree ${ }^{3}$ that the rule found early expression in the practice of $17^{\text {th }}$ century English courts strictly construing statutes that purported to displace the "benefit of clergy" (a common law doctrine that provided exceptions to the death penalty for certain eligible defendants and crimes). ${ }^{4}$ Some even seek to trace the origins of the rule to Byzantine

United States v. Wiltberger, 18 U.S. (5 Wheat.) 76, 95 (1820) ("The rule that penal laws are to be construed strictly, is perhaps not much less old than construction itself."').

2 Jeremy Bentham, A Comment on the Commentaries: A Criticism of William Blackstone's Commentaries on the Laws of England 141 (Charles W. Everett ed., Oxford Univ. Press 1928) (1776).

3 Modern historians of the rule include: Livingston Hall, Strict or Liberal Construction of Penal Statutes, 48 Harv. L. Rev. 748, 749-51 (1934); Jerome Hall, Theft, Law AND Society 356-63 (2nd ed. 1952); George W. Dalzell, Benefit of Clergy in America \& Related Matters (John F. Blair ed., 1955); J. M. Beattie, Crime and The Courts in England, 1660-1800 141-48 (Princeton Univ. Press 1986); William N. Eskridge, Jr., All About Words: Early Understandings of the "Judicial Power" in Statutory Interpretation, 1776-1806, 101 Colum. L. Rev. 990, 1057 (2001); Amy Coney Barrett, Substantive Canons and Faithful Agency, 90 B.U. L. REv. 109, 129-30 (2010).

4 For early English scholarship describing the rule see: SAmuel E. ThORnE, A Discourse UPON THE EXPOSICION AND UNDERSTANDINGE OF STATUTES, 154-55 (Lawbook Exchange 2003, first pub. approx. 1567) ("for the lawe always favoureth hym that goeth to wracke, nor it will pulle him on the nose that is on his knees."); ThOmas Coventry, Thomas Littleton \& Edward Coke, A Readable Edition of Coke upon Littleton $\S \S 54 b$, 153b, 238b (London, Saunders \& Benning 1830) (expressing the general rule that penal laws were not to be extended by equity); 1 William Blackstone, Commentaries *88 (recounting two cases: one in which an English court strictly construed a statute prohibiting the stealing of "horses" such that it was inapplicable to the stealing of a single horse; and a second case in which a statute punishing theft of "sheep, or other cattle" was read only to apply to sheep); 1 Matthew Hale, The History of the Pleas OF THE CROWN 469-70 (R.H. Small, 1st American ed. 1847) (recounting a 1639 case in which the court narrowly interpreted a statute making certain acts of manslaughter punishable by death); $I d$. at vol. 2, 335, 371 ("That where any statute...ousted clergy in any of those felonies, it is only so far ousted, and only in such cases and as to such persons as are expressly comprised within such statutes, for in favorem vitae \& privilegii clericalis such statutes are construed literally and strictly."); WiLliam Hawkins, A Treatise of the Pleas of the Crown 343 (1716-1721); Michael Foster, A Report of Some Proceedings on the Commission of Oyer and Terminer and Goal Delivery For the Trial of the Rebels in the Year 1746 In the County of SurRy, and of Other Crown Cases. To Which Are Added Discourses upon a Few Branches of The Crown Law 126-27 (Oxford, Clarendon Press, 1762) ("The Principle is true, that in Prosecutions on Penal Statutes the Words of the Statute are to be pursued. But it is equally true, that We are not to be governed by the Sound, but by the Well-known, True, Legal Import of the Words"); Michael Foster, A Report of Some Proceedings on The Commission of Oyer and Terminer and Goal Delivery for the Trial of the Rebels in the Year 1746 in the County of Surry, and of Other Crown Cases. To Which Are Added Discourses upon a Few Branches of the Crown Law 357-59 (Dublin, Sarah Coi 1763); 4 Matthew Bacon, A New Abridgment of the Law 651 
times. ${ }^{5}$ Despite its shared ancestry, the rule has evolved in different ways in most common law jurisdictions. This article will explore some of these differences by tracing the origins and evolution of the rule in two illustrative contexts - Australia and the United States.

A comparison between Australian and the United States has at least three reasons to recommend it. First, both the Australian and United States' rules share the same source, namely, the common law of England. Secondly, apart from both being common law systems, Australia and the United States share a number of relevant constitutional features, notably: a written constitution; a separation of legislative, judicial and executive power; and a federal structure. The third reason to believe that a comparison between the two jurisdictions might prove informative is that that Australian judges discussing the rule regularly draw upon decisions of the United States Supreme Court. ${ }^{6}$

This article will proceed in four parts. First, some terminological clarifications and a statement of the scope of the rule for the purposes of this article. Secondly, a discussion of the rule's origin and development in Australia. Thirdly, a discussion of the United States context. Finally, an effort to explain the similarities and divergences in the evolution of the rule in Australia and the United States.

\section{Some Terminological Ground-Clearing}

Before launching into the discussion proper it is necessary to clarify some of the terms used in this article. The first point of clarification pertains to the rule's title, or shorthand label. In Australia, the rule is rarely referred to as the rule of lenity, ${ }^{7}$ and is more commonly described as the rule that "where there is doubt about the

(Dublin, Luke White, 6th ed. 1793) ("“P]enal laws are to be construed strictly; yet even in the Construction of these, the Intention of the Legislators ought to be regarded.").

5 Geoffrey P. Miller, Pragmatics and the Maxims of Interpretation, 1990 Wis. L. Rev. $1179,1189-90$ (1990) nn.47-8 (seeking to draw a parallel between the rule and one of the maxims contained in the Digest of Justinian). See also Jerome Hall, General PRINCIPLES OF CRIMINAL LAW 20-27 (1947) (tracing the related principle of nulla poena sine lege to ancient Roman times).

6 Scott v. Cawsey (1907) 5 CLR 132, 156-57 (Austl.); Brown v. Tasmania (2017) 261 CLR 328, 497 (Austl.).

7 Exceptional uses of the "lenity" label in Australia include six judicial decisions, two transcripts of oral argument in the High Court, and one book chapter: Alcan (NT) Alumina Pty Ltd v. Commissioner of Territory Revenue (Northern Territory) (2009) 239 CLR 27, 49 (Austl.); City of Swan v. Gurney (2011) 186 LGERA 19, 30 (Austl.); Walker Corporation Pty Limited v. Director-General Department of Environment, Climate Change and Water (2012) 82 NSWLR 12, 21 (Austl.); Tabcorp Holdings Limited \& Tatts Group Limited v. The Treasurer of Victoria [2013] VSC 324, [27] (Austl.) n.16 (referring to Alcan (NT) Alumina (2009) 239 CLR 27 (Austl.)); James McDonald v. Racing New South Wales [2017] NSWSC 1511, [19], [35] (Austl.); Ultra Tune Australia Pty Ltd v. Australian Competition and Consumer Commission [2019] FCAFC 164, [41], [46] (Austl.); Kuru v. State of New South Wales [2008] HCATrans 152 (17 April 2008) (Austl.); Commissioner of Territory Revenue v. Alcan (NT) Alumina Pty Ltd [2009] HCATrans 150 (23 June 2009) (Austl.); Jeremy Gans, Legality and Lenity, in THE Principle of Legality in Australia and New Zealand (Dan Meagher \& Matthew Groves eds., 2017). 
meaning of a penal statute it should be resolved in favour of the subject". ${ }^{8}$ In the United States, the rule is now most commonly referred to as "the rule of lenity". The American phraseology remains a modern phenomenon, dating back only to 1958. ${ }^{10}$ Prior to that time, the rule was generally called the rule of strict construction or, in the fuller sense, "[t]he rule that penal laws are to be construed strictly". ${ }^{11}$ The modern move away from the language of "strict construction" is a welcome development, as that label was apt to confuse. This is because, according to a holistic conception of the rule, while ambiguous provisions creating criminal liability will be construed strictly (against the State), ambiguous provisions excusing a defendant from liability - for example, statutory defences or excuses - will be interpreted liberally (in favor of the subject). ${ }^{12}$ In any event, the Supreme Court has described the rule of lenity and the rule of strict construction as "identical twins" ${ }^{13}$ and most of the academic literature treats them as such. ${ }^{14}$ Accordingly, for the remainder of this article, no distinction is drawn between them. ${ }^{15}$

Unfortunately, titular matters are not the only aspects of the rule requiring clarification; courts in Australia and the United States tend to be somewhat undecided on two further questions:

i. what is meant by "penal" laws - i.e. what type of statutes engage the rule?; and

ii. what is meant by "ambiguity" - i.e. what degree of statutory ambiguity is required before the rule is engaged?

See Aubrey v. The Queen (2017) 260 CLR 305, 325-26 (Austl.).

9 See Shaw v. United States, 137 S. Ct. 462, 469 (2016) (finding insufficient ambiguity to call for application of "the rule of lenity").

10 Gore v. United States, 357 U.S. 386, 391 (1958) (Frankfurter, J.). Earlier uses of the term "lenity" to similar effect can be seen in Ex parte Davis, (No. 3,613) 7 F. Cas. 45, 49 (1851) (quoting from scholarly work: "it was ... one of the laws of the twelve tables of Rome that whenever there was a question between liberty and slavery, the presumption should be on the side of liberty. This excellent principle our law has adopted, in the construction of penal statutes; for whenever any ambiguity arises in a statute, introducing a new penalty or punishment, the decision shall be on the side of lenity and mercy"); Bell v. United States, 349 U.S. 81, 83 (1955) (Frankfurter, J.) ("When Congress leaves to the Judiciary the task of imputing to Congress an undeclared will, the ambiguity should be resolved in favor of lenity. . . . It may fairly be said to be a presupposition of our law to resolve doubts in the enforcement of a penal code against the imposition of a harsher punishment."); United States v. Turley, 352 U.S. 407, 418 (1957) (Frankfurter, J.) (referring to "the principle of lenity").

11 United States v. Wiltberger, 18 U.S. (5 Wheat.) 76, 95 (1820).

12 Hall, supra note 3, at 749 ("Under the rule, an ambiguous statutory determinable imposing or enlarging criminal liability will be construed narrowly, while such a determinable relieving from or diminishing liability will be construed broadly, so that the particular determinate will be placed with reference to the statutory determinable where it is of most advantage to the accused.").

13 Sedima v. Imrex Co., Inc., 473 U.S. 479, 491 n.10 (1985). See also the equation of the two concepts in United States v. Lanier, 520 U.S. 259, 266 (1997).

14 See, e.g., Dan M. Kahan, Lenity and Federal Common Law Crimes, 1994 Sup. Cт. Rev. 345, 346 n.1 (1994).

15 Contrast a Senate Report proposing a statue to eliminate the doctrine of strict construction, which claimed to leave intact the rule of lenity. See Sen. Rep. No. 95-605 23-24 (1977). 
In Australia, there does not appear to be consensus as to the sort of statute that will engage the rule. ${ }^{16}$ In general, invocations of the rule refer simply to "penal" statutes. ${ }^{17}$ More specific articulations of the rule sometimes refer to "statutes creating offences", ${ }^{18}$ or statutes that have "enlarged" an offence or that might be read as "extending any penal category". ${ }^{19}$ Nevertheless, the rule has also been applied to non-criminal statutes, for example, legislation pertaining to government powers of property confiscation ${ }^{20}$ and deportation. ${ }^{21}$ Further difficulties arise when a statute contains an amalgam of penal and remedial provisions. ${ }^{22}$

In the United States, the position appears to be no clearer. Although the courts agree that the rule is engaged by all "criminal statutes", ${ }^{23}$ there is uncertainty as to the application of the rule to hybrid statutes incorporating both criminal and civil provisions. ${ }^{24}$ This uncertainty has been compounded by the ill-defined interaction of Chevron $^{25}$ deference and the rule. ${ }^{26}$ To resolve these debates is beyond the scope of

16 For an illustration of this uncertainty see the exchange in oral argument between David Jackson QC and Justice Crennan in Commissioner of Territory Revenue v. Alcan (NT) Alumina Pty Ltd [2009] HCATrans 150 (23 June 2009) (Austl.). Then see the decision, which deliberately skirts the issue: Alcan (NT) Alumina Pty Ltd v. Commissioner of Territory Revenue (Northern Territory) (2009) 239 CLR 27, 49 (Austl.).

17 See, e.g., Aubrey v. The Queen (2017) 260 CLR 305, 325-26 (Austl.).

18 Beckwith v. The Queen (1976) 135 CLR 569, 576 (Austl.).

19 R v. Adams (1935) 53 CLR 563, 567-68 (Austl.).

20 Murphy v. Farmer (1988) 165 CLR 19, 28-29 (Austl.).

21 Minister for Immigration \& Multicultural Affairs v. Dhingra (2000) 98 FCR 1, 25. See, generally, D. C. Pearce \& R. S. Geddes, Statutory Interpretation in Australia 382-83 (8th ed. 2014); Perry Herzfeld \& Thomas Prince, Statutory Interpretation PRINCIPLES 261-62 (2014).

22 Pearce \& Geddes, supra note 21, at 357.

23 McNally v. United States, 483 U.S. 350, 359-60 (1986); see also United States v. Canal Barge Co., 631 F.3d 347, 353 (6th Cir. 2011) ("the rule of lenity is typically invoked only when interpreting the substantive scope of a criminal statue or the severity of penalties that attach to a conviction - not the venue for prosecuting the offense.").

24 See, e.g., United States v. Thompson/Centre Arms Co., 504 U.S. 505, 518 (1992); Crandon v. United States, 494 U.S. 152, 158, 168 (1990). See generally Bruce A. Markell, Bankruptcy, Lenity, and the Statutory Interpretation of Cognate Civil and Criminal Statutes, 69 IND. L.J. 335 (1994).

25 Chevron U.S.A. Inc. v. Natural Resources Defense Council, Inc., 467 U.S. 837, 844 (1984) (holding that, when a statute is "silent or ambiguous", and an administrative agency has resolved that silence in a "reasonable" way, courts should defer to the agency's interpretation of the statute).

26 The Supreme Court has not definitively resolved the question of whether Chevron applies to criminal statutes. See, generally, Babbitt v. Sweet Home Chapter of Cmtys. for a Great Or., 515 U.S. 687, 704 n.18 (1995) ("We have never suggested that the rule of lenity should provide the standard for reviewing facial challenges to administrative regulations whenever the governing statute authorizes criminal enforcement. Even if there exist regulations whose interpretations of statutory criminal penalties provide such inadequate notice of potential liability as to offend the rule of lenity, the [present] regulation ... cannot be one of them."); Crandon v. United States, 494 U.S. 152, 177 (1990) (Scalia, J., dissenting) ("a criminal statute is not administered by any agency but by the courts ... The Justice Department, of course, has a very specific responsibility to determine for itself what this statute means, in order to decide when to prosecute; but we have never thought that the interpretation of those charged with prosecuting criminal statutes is entitled to deference.”); United States v. Thompson/Center Arms Co., 504 
this article. As such, it is convenient to proceed by reference to the uncontroversial core of the rule, namely, its application to legislative provisions that create or extend criminal liability.

The final terminological issue warranting mention is the "ambiguity" precondition to the rule's application. ${ }^{27}$ How much ambiguity is required before a statute will be deemed ambiguous for the purposes of the rule? ${ }^{28}$ In Australia, the threshold requirement for ambiguity has found varied expression. For instance, the High Court has suggested that all that is needed to engage the rule is "doubt about the meaning of a penal statute". ${ }^{29}$ Earlier case law required "a fair and reasonable doubt" about the meaning of statutory language before the rule would be engaged. ${ }^{30}$ The most recent pronouncement of the High Court on the topic suggests that what is needed is "real" ambiguity. ${ }^{31}$ In America, Justice Scalia, writing extra-judicially with Bryan Garner, called for a similar threshold test: "The criterion we favour is this: whether, after all the legitimate tools of interpretation have been applied, 'a reasonable doubt persists"." 32 Others in the United States have said that "grievous

U.S. 505, 518 (1992) (applying lenity and declining to defer to agency interpretation of a tax statute); Leocal v. Ashcroft, 543 U.S. 1, 11 n.8 (2004) (giving no weight, in deportation proceedings, to the Immigration and Naturalization Service's view that petitioner's two convictions for DUI causing serious bodily injury were "crime[s] of violence" within the meaning of 18 U.S.C. $\$ 16$, a criminal statute); Abramski v. United States, 134 S. Ct. 2259, 2274 (2014) ("Whether the Government interprets a criminal statute too broadly [as it sometimes does] or too narrowly ... a court has an obligation to correct its error."); Whitman v. United States, 135 S. Ct. 352, 352-53 (2014) (Scalia, J., joined by Thomas, J., concurring in the denial of certiorari) ("A court owes no deference to the prosecution's interpretation of a criminal statute. . . . legislatures, not executive officers, define crimes.").

27 For a survey of interpretative approaches requiring "ambiguity" as a trigger to their application see Brett Kavanaugh, Fixing Statutory Interpretation, 129 HARv. L. REv. 2118, 2134-44, and the cases cited at $2143 \mathrm{n} .131$ (2016). For further commentary on the problematic ambiguity threshold for many interpretative inquiries see Frank H. Easterbrook, The Absence of Method in Statutory Interpretation, 84 U. CHI. L. Rev. 81, 90 (2017); Ward Farnsworth, Dustin F. Guzior \& Anup Malani, Ambiguity About Ambiguity: An Empirical Inquiry into Legal Interpretation, 2 J. Legal ANALYSIS 257 (2010); Brian G. Slocum, The Importance of Being Ambiguous: Substantive Canons, Stare Decisis, and the Central Role of Ambiguity Determinations in the Administrative State, 69 MD. L. Rev. 791 (2010); Lawrence M. Solan, Pernicious Ambiguity in Contracts and Statutes, 79 CHI.-Kent L. Rev. 859 (2004); Meredith A. Holland, Note, The Ambiguous Ambiguity Inquiry: Seeking to Clarify Judicial Determinations of Clarity Versus Ambiguity in Statutory Interpretation, 93 Notre Dame L. Rev. 1371 (2018).

28 See Antonin Scalia, A Matter of Interpretation 28 (1997) ("Every statute that comes into litigation is to some degree 'ambiguous'; how ambiguous does ambiguity have to be before the rule of lenity ... applies?"); see also United States v. Hansen, 772 F.2d 940, 948 (D.C. Cir. 1985) (Scalia, J.) (observing that the rule provides "little more than atmospherics, since it leaves open the crucial question - almost invariably present - of how much ambiguousness constitutes an ambiguity.").

29 See Aubrey v. The Queen (2017) 260 CLR 305, 325-26 (Austl.).

30 Chandler and Co v. Collector of Customs (1907) 4 CLR 1719, 1734 (Austl.) (quoting Nicholson v. Fields (1862) 31 L.J. Ex. 233, 235 (UK)).

$31 \quad$ R v. A2 [2019] HCA 35, [52] (Austl.).

32 Antonin Scalia \& Bryan Garner, Reading LaW: The Interpretation of Legal Texts 299 (2012) (quoting Moskal v. United States, 498 U.S. 103, 108 (1990)). 
ambiguity" is required before the rule can be engaged..$^{33}$ Yet others have said that the rule is engaged "only when the equipoise of competing reasons cannot otherwise be resolved." ${ }^{34}$ For present purposes, it is sufficient to acknowledge the controversy over the meaning of "ambiguity" rather than attempt to resolve it.

\section{The Australian Story ${ }^{35}$}

\section{A. EARLY CASE LAW FROM the High Court}

A number of early decisions of the High Court make reference to the rule. An illuminating example is the case of Scott v Cawsey, ${ }^{36}$ which is commonly cited as the earliest authoritative Australian statement of the rule. ${ }^{37}$ In that case, the Court had to determine whether Mr Cawsey had been properly penalized as "keeper of a disorderly house" within the meaning of an offence provision in the Sunday Observance Act $1780 .{ }^{38}$ Of the five Justices on the bench, four ${ }^{39}$ explicitly discussed the rule. While the remaining Justice only engaged with the topic implicitly, ${ }^{40}$ his views on the rule can be gleaned from a decision delivered later in the same year, in which he outlined his interpretative approach to penal statues. ${ }^{41}$

33 Chapman v. United States, 500 U.S. 453, 463 (1991) (quoting Huddleston v. United States, 415 U.S. 814, 831 (1974)).

34 Johnson v. United States, 529 U.S. 694, 713 n.13 (2000) (Souter, J.); cf. SCALIA \& A. GARNER, supra note 32, at 298 (arguing that if Justice Souter's "equipoise" threshold was required then "the rule would either never apply ... or would be superfluous").

35 This analysis, like the analysis of the United States' rule, begins with the formation of the federal system. This article therefore does nothing to ameliorate the dearth of scholarship on pre-Federation statutory interpretation in the Australian colonies.

36 Scott v. Cawsey (1907) 5 CLR 132 (Austl.).

37 For scholars citing Scott v. Cawsey (1907) 5 CLR 132 (Austl.) as an early authoritative statement of the rule see PEARCE AND GEDDEs, supra note 21, at 367; Gans, supra note 7, at 189-208, 199-201. The case is not in fact the earliest High Court consideration of the rule, but it is perhaps the earliest comprehensive discussion of it. For earlier decisions touching on the rule see: Master Retailers' Association of New South Wales v. Shop Assistants Union of New South Wales (1904) 2 CLR 94, 106 (Austl.) ("the old distinction between remedial and penal Acts has of late years been much discredited. What has been laid down in modern cases is that the duty of the Court is to interpret Acts according to the intent of the Parliament which passed them."); Prior v. Sherwood (1906) 3 CLR 1054, 1072 (Austl.) ("This Act is a penal one, and without troubling our heads very much with the strength or effect of the statement that a penal Act should be construed strictly ... a short and clear way of putting the matter [is] 'that the Court in construing such a Statute must see that the thing charged is an offence within the plain meaning of the words used, so as to carry out the true intention of the legislature" citations omitted); Hamilton v. Warne (1907) 4 CLR 1293, 1297, 1302 (Austl.) ("the provisions of the law as to acts of insolvency have always been construed strictly. An analogy ... may be found in the rule for the construction of provisions creating a forfeiture." And "The proceedings are quasi-penal; and his conduct must come strictly within the words of the Act in order to justify the Court making the order absolute.").

38 Scott v. Cawsey (1907) 5 CLR 132, 142 (Barton, J.) (Austl.).

39 Id. at 141 (Griffiths, C.J.), 144-45 (Barton, J.), 154-55 (Isaacs, J.), 173 (Higgins, J.).

$40 \quad I d$. at 151 (O'Connor, J.).

41 Chander and Co. v. Collector of Customs (1907) 4 CLR 1719, 1734-35 (Austl.). 
Of the majority, Chief Justice Griffith did not find the statute to be ambiguous and, accordingly, held that the rule was not engaged. Nevertheless, in obiter dicta, his Honour noted that in "a case of ambiguity ... the construction in favour of liberty should be adopted." ${ }^{42}$ Justice Barton engaged more substantively with the rule, referring to Blackstone ${ }^{43}$ and three separate English authorities ${ }^{44}$ The burden of Justice Barton's observations was that the rule required that the court not "strain" the words of a penal statute to extend it beyond those acts "distinctly" or "strictly" within the "plain meaning of the words used". ${ }^{45}$ Importantly, for Justice Barton, where statutory words permit of two equally plausible interpretations, the courts must prefer that which favors the defendant. ${ }^{46}$ Justice O'Connor reached the same conclusion as the majority without explicitly referring to the rule. Instead, his Honour invoked the separation of powers concerns animating the rule:

"where a Statute constitutes the committing of certain acts a criminal offence ... [it is not] the duty of a Court to so add to the language of a Statute as to make it include the committing of acts of the same kind which lead to the same result, but which the legislature has not constituted an offence. To do so would be to make laws, not to interpret them." ${ }^{47}$

Of the minority, Justice Higgins only engaged with the rule in passing, expressing agreement with the idea that a person ought only be found to have violated a penal statue where their acts fall within "the letter and spirit of the law". ${ }^{48}$ Justice Isaacs, the other dissenting Justice, engaged extensively with English case law and commentary on the rule. Departing from the statements of Chief Justice Griffiths and Justice Barton, Justice Isaacs expressed the view that, where two constructions are left open by the words of the statute, courts ought to prefer that which best gives effect to the intent of the legislature- even where that intent may disfavor the defendant. ${ }^{49}$ His Honour was prepared to go even further, holding that a court would be permitted to employ the full flexibility of the statutory words to effectuate the intention of the legislature, even where doing so would involve the court departing

42 Scott v. Cawsey (1907) 5 CLR 132, 141 (Griffiths, C.J.) (Austl.). It is interesting to contrast this utterance with his Honour's remarks just a few years earlier in Master Retailers' Association of New South Wales v. Shop Assistants Union of New South Wales (1904) 2 CLR 94, 106 (Austl.) ("the old distinction between remedial and penal Acts has of late years been much discredited. What has been laid down in modern cases is that the duty of the Court is to interpret Acts according to the intent of the Parliament which passed them.")

43 William Blackstone, Commentaries *88 ("The law of England does not allow of offences by construction.") quoted in Scott v. Cawsey (1907) 5 CLR 132, 145 (Barton, J.) (Austl.).

44 Reid v. Wilson (1895) 1 WB 315, 320, 322 (UK); Dyke v. Elliot; The Gauntlet (1872) LR 4 PC 184, 191 (UK); Dickenson v. Fletcher (1873) LR 9 CP 1, 7 (UK) all quoted in Scott v. Cawsey (1907) 5 CLR 132, 144-45 (Barton, J.) (Austl.).

45 Scott v. Cawsey (1907) 5 CLR 132, 144-45 (Barton, J.) (Austl.).

$46 \quad I d$. at 145 (Barton, J.).

47 Id. at 151 (O'Connor, J.).

$48 \quad I d$. at 173 (Higgins, J.) (emphasis added).

49 Id. at 155-56 (Isaacs, J.) (referring to Llewellyn v. Vale of Glamorgan Railway Co (1898) 1 WB 473, 478 (UK)). 
from an alternative, plausible, literal interpretation. ${ }^{50}$ Importantly for present purposes, Justice Isaacs went on to refer to three decisions of the Supreme Court of the United States, ${ }^{51}$ which he considered to mirror his own views. (It is perhaps possible to read these cases as standing for a narrower proposition than that which Justice Isaacs advances, but there is no doubt that they do emphasize the statutory purpose in a way that the traditional rule does not.)

What the various opinions in Cawsey helpfully illustrate is that, even in the High Court's early days, the scope of the rule was hotly contested. The issue that separated the Justices in Cawsey, at least with respect to the rule, was the degree to which legislative intent could be relied upon to save a penal statute from ambiguity (and the application of the rule). On the one hand, most of the Justices conceived of the rule as coming into play whenever the legislature fails to bring conduct within the "plain meaning" 52 or "distinct[ words]" 53 of the statute. One might label this strong version of the rule a "textualist" approach to strict construction, because of the primacy it affords the statutory language. Such an approach can be seen in other early High Court authorities. For example, a year after Cawsey, Justice Barton referred back to that case before restating the Court's "duty ... not to give greater force to the language of the legislature than it will clearly bear" ${ }^{54}$

On the other side of the conceptual divide, Justice Isaacs conceived of a less powerful rule, which would only come into play if legislative intent could not be relied upon to clarify ambiguous words. This view found support in the extended treatment of the rule by Justice O'Connor in Chandler \& Co $v$ Collector of Customs, a judgment handed down just two weeks after Cawsey. O'Connor wrote that the rule was engaged in cases where there was "a fair and reasonable doubt" about the meaning of statutory language..$^{55}$ His Honour then went on to make clear that such a doubt would not arise merely from textual ambiguity:

"The existence of an ambiguity in the words to be construed does not necessarily create a doubt. It is a reason for an examination of the context, the scope and object of the enactment. But that examination may

$50 \quad$ Scott v. Cawsey (1907) 5 CLR 132, 155-56 (Isaacs, J.) (Austl.) (referring to Caledonian Railway Co v. North British Railway Co (1881) 6 App. Cas. 114, 122 (UK)). It important to note the error of Justice Isaacs' reference to Caledonian Railway Co. That case did not concern the interpretation of a penal statute and, for that reason, cannot be read to support the broad proposition for which Justice Isaacs sought to deploy it.

51 Johnson v. Southern Pacific Co 196 U.S. 1, 17, 18 (1904); United States v. Lacher 134 U.S. 624 (1890); United States v. Winn 3 Sumn. 209 (1838) all quoted in Scott v. Cawsey (1907) 5 CLR 132, 156-57 (Isaacs, J.) (Austl.).

52 Scott v. Cawsey (1907) 5 CLR 132, 145 (Barton, J.) (Austl.) (quoting Dyke v. Elliott; The Gauntlet (1872) LR 4 PC 184, 191 (UK)). See also Prior v. Sherwood (1906) 3 CLR 1054, 1072 (Austl.) (quoting Powell v. Kempton Park Racecourse Co. (1897) 2 QB 242, 298 (UK)) ("the Court in construing such a Statute must see that the thing charged is an offence within the plain meaning of the words used, so as to carry out the true intention of the legislature.")

53 Scott v. Cawsey (1907) 5 CLR 132, 145 (Barton, J.) (Austl.) (quoting Dickenson v. Fletcher (1873) LR 9 CP 1, 7 (UK)).

54 Lyons v. Smart (No 1) (1908) 6 CLR 143, 158 (Barton, J.) (Austl.) (emphasis added).

55 Chandler and Co v. Collector of Customs (1907) 4 CLR 1719, 1734 (O’Connor, J.) (Austl.) (quoting Nicholson v Fields (1862) 31 L.J. Ex. 233, 235 (UK)). 
satisfy the Court beyond all doubt as to the meaning to be placed on an expression which is on its face ambiguous. I take it, therefore, that in the interpretation of a penal or taxing Statute mere ambiguity of expression or loose or inaccurate language will not prevent a Court from giving effect to the meaning of the legislature if, by the application of the ordinary rules of construction applicable to all other Statutes, that meaning can be ascertained. If, notwithstanding a careful examination ... a doubt still remains ... the Court is not at liberty to resolve the doubt against the accused" ${ }^{56}$ (emphasis added)

The tension between the strong, textualist version of the rule championed by Justice Barton and the more qualified version of the rule expressed by Justice Isaacs, makes Cawsey an important early consideration of the rule. Unsurprisingly, that case has been cited by the High Court on a number of subsequent occasions, both in reliance on the words of the majority Justices and for the remarks of Justice Isaacs in dissent. ${ }^{57}$ This article will now turn to the manner in which this early tension has finally been resolved in modern and contemporary High Court case law.

\section{B. Modern and Contemporary Case LaW: The “Last Resort” Rule}

In the years since Cawsey, Justice Isaacs' qualified version of the rule has ultimately prevailed. ${ }^{58}$ The slow dilution of the rule's originally potent concentrate is exemplified in the case of Beckwith $v$ The Queen, ${ }^{59}$ which one scholar has described as marking the "low ebb" of the rule in modern Australian jurisprudence. ${ }^{60} \mathrm{In}$ Beckwith, Justice Gibbs did much to entrench the qualified version of the rule, asserting:

"The rule formerly accepted, that statutes creating offences are to be strictly construed, has lost much of its importance in modern times. In determining the meaning of a penal statute the ordinary rules of construction must be applied, but if the language of the statute remains ambiguous or doubtful the ambiguity or doubt may be resolved in favour of the subject by refusing to extend the category of criminal offences ... The rule is perhaps one of last resort." ${ }^{91}$

${ }^{6}$ Chandler and Co v. Collector of Customs (1907) 4 CLR 1719, 1735 (O’Connor, J.) (Austl.).

7 See, e.g., Lyons v. Smart (No 1) (1908) 6 CLR 143, 157 (Austl.); Brott v. The Queen (1992) 173 CLR 426, 438 n.43 (Austl.); R v. Lavender (2005) 222 CLR 67, 95 n.94 (Austl.); R v. Holliday (2017) 260 CLR 650, 674 n.75 (Austl.); Brown v. Tasmania (2017) 261 CLR 328, 497 (Austl.).

58 Pearce AND GedDes, supra note 21, at 367-68 ("The approach more frequently used nowadays by the courts was enunciated by Isaacs J in Scott $v$ Cawsey . . . The mere discovery of an ambiguity in a penal statute should not automatically mean that a defendant must be acquitted. . . . the court must endeavour to resolve that ambiguity by the application of the various aids to construction that are applicable to all statutes. Then, and only then, if a doubt still remains as to the meaning of the penal provision should the issue be resolved in favour of the defendant.").

59 Beckwith v. The Queen (1976) 135 CLR 569 (Austl.).

60 Gans, supra note 7, at 199.

61 Beckwith v. The Queen (1976) 135 CLR 569, 576 (Austl.) (citations omitted). 
After Gibbs assumed the Chief Justice's chair, the above passage was subsequently quoted with approval by a majority of the High Court in Waugh v Kippen, where it was said to reflect "the modern approach in construing penal statutes". ${ }^{62}$ In addition to Waugh, Beckwith has been cited in over twenty High Court decisions for its statement of the rule. ${ }^{63}$ In light of this tidal wave of High Court authority, there can be little doubt that the rule is now confined to its limited version. On this version, the rule is only engaged if ambiguity remains after all of "the ordinary rules of construction [have been] applied". ${ }^{64}$ This means that a court will only apply the rule of lenity after it has had regard to text, context (including legislative history), purpose and any applicable provisions of an interpretation statute.

Nevertheless, before leaving these cases it is worth noting that, in the final result in Beckwith, Justice Gibbs in fact applied the rule in favor of the defendant, writing: "The effect of the [statutory] provisions at least remains doubtful and that doubt should be resolved in favour of the liberty of the subject." ${ }^{65}$ Furthermore, while there is no room left to doubt the reasoning in Waugh, it should be remembered that the statute in that case contained both penal and remedial provisions and, as such, does not provide a perfect analog for cases raising the application of the rule to purely penal statutes.

\section{A Constitutional Dimension?}

Unlike the United States - to be discussed below - Australian courts very rarely suggest that the rule might have a constitutional dimension. It will be recalled, however, that in the earliest High Court case to authoritatively apply the rule, Cawsey, Justice O'Connor invoked the separation of powers to rationalize the strict construction of the penal provision under consideration. Similarly, in the early case of Lyons $v$ Smart (No 1), Justice Barton quoted from American

62 Waugh v. Kippen (1986) 160 CLR 156, 164 (Austl.).

63 See Gallagher v. Attorney-General (Cth) (1983) 152 CLR 238 (Austl.); Barker v. The Queen (1983) 153 CLR 338 (Austl.); He Kaw The v. The Queen (1985) 157 CLR 523 (Austl.); Kingswell v. The Queen (1985) 159 CLR 264 (Austl.); O'Sullivan v. Lunnon (1986) 163 CLR 545 (Austl.); Brott v. The Queen (1992) 173 CLR 426 (Austl.); Telstra Corporation Ltd v. Australasian Performing Right Association Ltd (1997) 191 CLR 140 (Austl.); Lee Vanit v. The Queen (1997) 190 CLR 378 (Austl.); Re Colina; Ex parte Torney (1999) 200 CLR 386 (Austl.); Cheng v. The Queen (2000) 203 CLR 248 (Austl.); Chief Executive Officer of Customs v. El Hajje (2005) 224 CLR 159 (Austl.); R v. Lavender (2005) 222 CLR 67 (Austl.); Stevens v. Kabushiki Kaisha Sony Computer Entertainment (2005) 224 CLR 193 (Austl.); White v. Director of Military Prosecutions (2007) 231 CLR 570 (Austl.); CTM v. The Queen (2008) 236 CLR 440 (Austl.); Australian Competition and Consumer Commission v. Channel Seven Brisbane Pty Ltd (2009) 239 CLR 305 (Austl.); Alcan (NT) Alumina Pty Ltd v. Commissioner of Territory Revenue (Northern Territory) (2009) 239 CLR 27 (Austl.); Public Trustee (Qld) v. Fortress Credit Corporation (Aust) 11 Pty Ltd (2010) 241 CLR 286 (Austl.); Agius v. The Queen (2013) 248 CLR 601 (Austl.); Alqudsi v. The Queen (2016) 258 CLR 203 (Austl.); Re Day (No 2) (2017) 263 CLR 201 (Austl.); Aubrey v. The Queen (2017) 260 CLR 305 (Austl.); R v. Holliday (2017) 260 CLR 650 (Austl.); Brown v. Tasmania (2017) 261 CLR 328 (Austl.); R v. A2 [2019] HCA 35 (Austl.).

64 Beckwith v. The Queen (1976) 135 CLR 569, 576 (Austl.).

$65 \quad I d$. at 578. 
authority ${ }^{66}$ to describe the different institutional functions of the legislative and the judicial branches of government, concluding that: "[the] duty [of the judiciary is] ... not to give greater force to the language of the legislature than it will clearly bear" ${ }^{67}$ Nevertheless, Justices Barton and O'Connor's attempts to ground the rule in Australia's constitutional structure remains an exception and, accordingly, it is unlikely that the rule will be found to have a constitutional basis in Australia any time soon.

\section{STATUTORY MODIFICATION}

An important aspect of Australian statutory interpretation is the role played by what this article will call "interpretation statutes", which statutes contain legislative directives as to how courts should engage in the task of statutory interpretation. Each jurisdiction in Australia has enacted such a statute, ${ }^{68}$ and each includes a purposive interpretation provision. ${ }^{69}$ Broadly speaking, there are two varieties of purposive interpretation provisions. ${ }^{70}$ For present purposes, the more prescriptive variety of provision needs to be considered, because if the rule can be squared with such a provision then it will certainly be reconcilable with the less prescriptive provision.

An example of the more prescriptive provision can be seen in $§ 15 \mathrm{AA}$ of the federal Acts Interpretation Act 1901:

"In interpreting a provision of an Act, the interpretation that would best achieve the purpose or object of the Act (whether or not that purpose or object is expressly stated in the Act) is to be preferred to each other interpretation.".71

At first blush, this might appear to create a potential for inconsistency with the rule. $^{72}$ The courts, however, have held that there is no contradiction between

United States v. Lacher, 134 U.S. 624, 628 (1890).

Lyons v. Smart (No 1) (1908) 6 CLR 143, 158 (Austl.).

68 Legislation Act, 2001 (A.C.T.); Interpretation Act, 1987 (N.S.W.); Interpretation Act, 1987 (N.T.); Acts Interpretation Act, 1954 (Qld.); Acts Interpretation Act, 1931 (Tas.); Interpretation of Legislation Act, 1984 (Vic.); Interpretation Act, 1984 (W. Austl.).

69 Pearce \& Geddes, supra note 21, at 42 (listing purposive interpretation provisions within each Australian jurisdiction's interpretation statute).

70 Pearce \& Geddes, supra note 21, at 42.

71 An earlier version read: "In the interpretation of a provision of an Act, a construction that would promote the purpose or object underlying the Act (whether that purpose or object is expressly stated in the Act or not) shall be preferred to a construction that would not promote that purpose or object." The change to the current wording occurred in 2011 and was effected by the Acts Interpretation Amendment Act, 2011 (Austl.), sched 1. Note the change from "a construction that would promote the purpose" to "the interpretation that would best achieve the purpose". The new wording is thought to be more prescriptive because, in the event "of a choice between two or more interpretations each of which would promote the Act's purpose or object, ... the interpretation that would best achieve that purpose or object must be chosen." Id. at 42.

72 See, e.g., Minister for Immigration \& Multicultural Affairs v. Dhingra (2000) 98 FCR 1, 27-28 (Hill, J.) (Austl.) ("If there were to be a conflict between the application of the common law rule [of strict construction] ... and the statutory rule [in s 15AA of the 
purposive interpretation provisions like s $15 \mathrm{AA}$ and the rule. ${ }^{73}$ Commentators have agreed. ${ }^{74}$ To avoid any doubt, two states - Queensland ${ }^{75}$ and South Australia ${ }^{76}$ - have explicitly qualified their liberal construction provisions to avoid any interference with the rule of strict construction..$^{77}$ The South Australia provision, for instance, provides:

\section{"Construction that would promote purpose or object of an Act to be preferred}

(1) Subject to subsection (2), where a provision of an Act is reasonably open to more than one construction, a construction that would promote the purposes or object of the Act (whether or not that purpose or object is expressly stated in the Act) must be preferred to a construction that would not promote that purpose or object.

(2) This section does not operate to create or extend any criminal liability."

\section{E. SUMMARY OF THE CURRENT AUSTRALIAN APPROACH}

In summary, the Australian rule of lenity is a common law creature (albeit with ill-defined constitutional roots) that has been largely unaffected by the legislative enactment of purposive interpretation provisions. Nevertheless, the Australian rule is one of "last resort", only applied after other interpretative methods have been exhausted and "ambiguity or doubt" remains. ${ }^{78}$ The rule has been understood and applied in this way in recent years. ${ }^{79}$

Acts Interpretation Act, 1901 (Austl.)], then it is obvious that the statutory rule would prevail.").

73 See, e.g., Minister for Immigration \& Multicultural Affairs v Dhingra (2000) 98 FCR 1, 26 (Burchett, J. and Branson, J.) (Austl.) ("it would be rarely, if ever, that the general provision made by s $15 \mathrm{AA}$ with respect to the interpretation of all statutes would be found to render nugatory the special rules which have always applied to particular types of statute, such as penal statutes."); Director-General Department of Land and Water Conservation v. Bailey (2003) 136 LGERA 242, 249 (Austl.) ("there would be no contradiction between [the traditional approach to penal statutes] and s 33 of the Interpretation Act, 1987 (N.S.W.) because to prefer the construction promoting the object and purpose of a statute is to apply it according to its terms.").

74 See, e.g., Pearce ANd Geddes, supra note 21, at 368-69.

75 Acts Interpretation Act $§ 141954$ (Qld.).

76 Acts Interpretation Act $\$ 221915$ (S. Austl.).

77 For a discussion of these provisions and their operation see Gans, supra note 7, at 20103 .

78 Beckwith v. The Queen (1976) 135 CLR 569, 576 (Austl.) (citations omitted).

79 Brown v. Tasmania (2017) 261 CLR 328, 497 (Austl.). 


\section{THE AMERICAN STORY ${ }^{80}$}

\section{A. EARly CASE LAW From the SUPREMe Court}

The rule first entered the federal law reports of the Supreme Court of the United States in 1820 via Chief Justice John Marshall's judgment in Wiltberger $v$ United States. ${ }^{81}$ In that case the Court was called upon to interpret a suite of provisions in the Crimes Act of 1790, the first criminal statute passed by the United States Congress. More specifically, the Court had to determine whether the manslaughter prohibition contained in $\S 12$, which prohibited homicides occurring "on the high seas", ought to be read to encompass a homicide on a river. Notwithstanding strong textual indications from other provisions suggesting that Congress had intended $\$ 12$ to be read to encompass acts done on rivers, the Court viewed the rule as commanding a strict construction of the penal provision to exclude coverage of rivers. Importantly, the Court reached this conclusion while acknowledging that it might have been contrary to "the obvious intent of the legislature" 82 and conceding that Mr Wiltberger's case was probably "within the reason or mischief of [the] statute" ${ }^{83}$ In this reasoning one can see that the early statement of the rule in the American context was close to the strong textualist version that found early support in Australia.

The strong, textualist version of the rule articulated in Wiltberger was justified on two bases: the rule's august common law heritage and the constitutional values underpinning it. In relation to the first rationale, Chief Justice Marshall wrote: "The rule that penal laws are to be construed strictly, is perhaps not much less old than construction itself." ${ }^{84}$ The Chief Justice's rhetorical strategy is unmistakeable, the authority of the Court's decision is being bolstered by reference to a higher order rule. This was an approach that the Marshall Court adopted not just in respect of the rule of lenity, but in respect of statutory interpretation more generally, to which Chief Justice Marshall sought to bring systems and certainty. ${ }^{85}$ Since

80 This analysis, like the analysis of the Australian rule, begins with the establishment of the federal judiciary. There is very little scholarship on the rule's existence (or nonexistence) in the case law of the American colonies and then the States prior to 1788. But see DALZELL, supra note 3.

81 United States v. Wiltberger, 18 U.S. (5 Wheat.) 76, 95 (1820); but see Lawrence M. Solan, Law, Language, and Lenity, 40 WM. \& MAry L. Rev. 57, 89-91 (1998) (arguing that the rule of lenity in fact entered Supreme Court jurisprudence 15 years earlier, in the case of United States v. Fisher, 6 U.S. (2 Cranch) 358, 386 (1805) ("where great inconvenience will result from a particular construction, that construction is to be avoided, unless the meaning of the legislature be plain; in which case it must be obeyed.")); see also Barrett, supra note 3, at $129 \mathrm{n} .91$ (suggesting that the earliest reported federal case to invoke the rule was Bray v. The Atalanta, 4 F. Cas. 37, 37 (D.S.C. 1794) (No. 1819) where it was said: "it is a penal law and must be construed strictly.").

82 United States v. Wiltberger, 18 U.S. (5 Wheat.) 76, 94 (1820).

83 Id. at 96.

84 Id. at 95. Here Marshall proves the truth of Alexis de Tocqueville's diagnosis of American (and English) lawyers: "Americans have retained the law of precedents . . . [and] a taste and a reverence for what is old". Alexis de ToCQUeville, Democracy IN AMERICA 139 (1831).

85 See John Choon Yoo, Note, Marshall's Plan: The Early Supreme Court and Statutory Interpretation, 101 Yale L. J. 1607, 1628 (1992). See also The Federalist No. 78 
Wiltberger, courts applying the rule have followed suit, invoking the rule's deep historical roots, presumably to provide additional justification for results that are often advantageous to a defendant and thus less palatable to the general public. ${ }^{86}$ For example, the Court has described the rule as "venerable" "87, "time-honored" 88 , "long-established", 89 "well-recognized" ", "traditional" "11 "familiar" "92, an "ancient requirement"

Notwithstanding the fact that, prior to Wiltberger, the rule was already being applied by federal courts, ${ }^{95}$ it is Wiltberger that is now the authoritative early American statement of the rule. ${ }^{96}$ Nevertheless, as will be seen in the following discussion, the strong, textualist version of the rule expressed in Wiltberger has not survived.

\section{B. Modern and Contemporary Case LaW: The “Tiebreaker” Rule}

Historians of the rule in America have described how the Wiltberger version of the rule was gradually eroded in the $20^{\text {th }}$ Century. Lawrence Solan has conducted

(Alexander Hamilton) ("To avoid an arbitrary discretion in the courts, it is indispensable that they shall be bound by strict rules and precedents.").

86 See Ross E. Davies, A Public Trust Exception to the Rule of Lenity, 63 U. Chi. L. Rev. 1175, 1182-83 (1996) ("History matters to the modern application of the Rule because the judges and justices who apply it say so. They do so in at least two ways: (1) history is frequently a factor in debates over canons of construction and terms of art developed at common law; and (2) historical support is a significant element of judicial rhetoric justifying the existence and importance of the Rule. History also matters from a practical standpoint, to the extent that historical acceptance of the Rule bolsters the credibility of the judicial actors who invoke it ..."). Note, however, that on at least two occasions the Supreme Court has announced the rule without any citation and on another occasion has doubted that the rule requires any citation. See Bell v. United States, 349 U.S. 81, 83-84 (1955); United States v. Universal C.I.T. Credit Corp., 344 U.S. 218, 221-22 (1952). See also United States v. Bramblett, 348 U.S. 503, 509 (1954) ("That criminal statutes are to be construed strictly is a proposition which calls for the citation of no authority.").

87 United States v. R.L.C., 503 U.S. 291, 305 (1992).

88 United States v. Kozminski, 487 U.S. 931, 952 (1988). See also Rewis v. United States, 401 U.S. 808, 812 (1971); Dowling v. United States, 473 U.S. 207, 229 (1985).

89 Dunn v. United States, 442 U.S. 100, 112 (1979).

90 United States v. Rodgers, 466 U.S. 475, 484 (1984).

91 Whalen v. United States, 445 U.S. 684, 703 (1980) (Rehnquist, J., dissenting).

92 Adamo Wrecking Co v. United States, 434 U.S. 275, 275 (1978).

93 United States v. R.L.C., 503 U.S. 291, 310 (1992) (Scalia, J., concurring) (citation omitted).

94 Id. at 310 (Scalia, J., concurring). (Quoting Hughey v. United States, 495 U.S. 411, 422 (1990)).

95 See Barrett, supra note 3, at 128-34 (describing the rule's development in the early Republic and concluding: "a review of early federal cases leaves one with the distinct impression that lenity was the most commonly applied substantive canon of construction. My searches yielded far more cases applying the rule of lenity than any other canon."); $c f$. Eskridge Jr., supra note 3, at 1069 ("Federal judges in the 1790s were not as willing [as their state counterparts] to supplement criminal statutes, but I was surprised by their reluctance to ameliorate their harsh operation either. Decisions showing criminal defendants lenity in the 1790s typically involved procedural rather than substantive rights." citations omitted).

96 United States v. Santos, 553 U.S. 507, 515 (2008) (referring to United States v. Wiltberger, 18 U.S. (5 Wheat.) 76 (1820) as "our seminal rule-of-lenity decision"). 
the most comprehensive review of the rule's application during this period. ${ }^{97} \mathrm{He}$ convincingly divides the rule's $20^{\text {th }}$ Century development into two chapters, both involving a progressive narrowing of the rule. First, one must consider the era of legal interpretation ushered in by the landmark decision in Church of the Holy Trinity. ${ }^{98}$ That case, decided in 1892 , is generally understood to mark the beginning of a more expansive approach to statutory interpretation at the Supreme Court. From that time onwards, the Court began to more readily consider legislative history and other extra-textual material in its attempts to divine the meaning of statutory text. Solan explains how this approach resulted in a de-prioritization of the rule. Instead of being applied in any case of textual ambiguity-even to override apparent statutory purpose (as appears to have occurred in Wiltberger) - the rule was only applied if the statute remained ambiguous after consideration of legislative history, context and other interpretative aids.

The second chapter in Solan's $20^{\text {th }}$ Century history of the rule is set in the Rehnquist Supreme Court (1986-2005). This period saw the rule have something of a renaissance, largely as a result of the championship of Justice Scalia. ${ }^{99}$ Yet the relative frequency of the rule's invocation did not translate into a stronger statement of its place in the interpretative process. In fact, for most members of the Court the rule came "dead last in the interpretative hierarchy." 100 So, for example, in Moskal $v$ United States the Court explained: "we have always reserved lenity for those situations in which a reasonable doubt persists about a statute's intended scope even after resort to 'the language and structure, legislative history, and motivating policies' of the statute." 101 Others on the Supreme Court during this period, notably Justice Scalia, took a different approach, whereby the rule was applied to resolve any ambiguity that might arise between a purely textualist approach and an approach based on extra-textual indicators. ${ }^{102}$ Nevertheless, Justice Scalia's approach did not

97 Solan, supra note 81, at 89-122 (tracking the progressive narrowing of the rule from the its early days, through Justice Frankfurter's influence, to the Rehnquist Court's lenity jurisprudence); see also Mila Sohoni, Notice and the New Deal, 62 Duke L.J. 1169, 1203-07 (2012) (largely adopting Solan's analysis that the arrival of Justice Frankfurter to the Supreme Court and the beginning of a new interpretative culture all contributed to the deprioritization of the rule).

98 Church of the Holy Trinity v. United States, 143 U.S. 457 (1892).

99 See, generally, Sarah Newland, Note, The Mercy of Scalia: Statutory Construction and the Rule of Lenity, 29 Harv. C.R.-C.L. L. Rev. 197-230 (1994).

100 Zachary Price, The Rule of Lenity as a Rule of Structure, 72 FordHam L. Rev. 885, 891 (2004); see also Kahan, supra note 14, at 425. ("Ranking lenity 'last' among interpretative conventions all but guarantees its irrelevance.").

101 Moskal v. United States, 498 U.S. 103, 108 (1990) (quoting Bifulco v. United States, 447 U.S. 381, 387 (1980)) (emphasis added). See also Abramski v. United States, 134 S. Ct. 2259, $2272 \mathrm{n} .10$ (2014) (where the majority did not reach the application of the rule of lenity because no statutory ambiguity remained after reference was had to "context, structure, history and purpose").

102 Moskal, 498 U.S. at 132 (Scalia, J., dissenting). See also Abramski, 134 S. Ct. at 228082 (Scalia, J.) (criticizing "the majority's miserly approach" whereby lenity ranked last in the interpretative hierarchy). Scalia has advocated for an even more ambitious, textualist rule of lenity in his extra-judicial writing, a rule that would apply to any textual ambiguity at all. See SCALIA \& GARNER, supra note 32, at 298 (noting the ideal rule would be that which "were automatically applied at the outset of textual inquiry, before any other rules of interpretation were invoked to resolve ambiguity. Treating it as a clear- 
find favor with other members of the Court and the rule is now generally understood to operate only as a "tiebreaker" 103 after all other interpretative methods have been exhausted. ${ }^{104}$

\section{Constitutional Foundations ${ }^{105}$}

As was foreshadowed above, the Court in Wiltberger did not rely solely on the rule's common law roots for its authority. Chief Justice Marshall also grounded the rule in constitutional values, writing:

"The rule that penal laws are to be construed strictly ... is founded on the tenderness of the law for the rights of individuals; and on the plain principle that the power of punishment is vested in the legislative, not in the judicial department. It is the legislature, not the Court, which is to define a crime, and ordain its punishment." 106

statement rule would comport with the original basis for the canon and would provide considerable certainty. But that is not the approach the cases have taken.").

103 United States v. Rodriquez, 553 U.S. 377, 404 (2007) (Souter, J., dissenting) (describing the rule as "a ready tiebreaker . . . which applies where [as here] we have seiz[ed] everything from which aid can be derived, but are left with an ambiguous statute" internal quotation marks omitted, citation omitted); United States v. Canal Barge Co., 631 F.3d 347, 353 (6th Cir. 2011) ("the rule of lenity is only a tiebreaker of last resort"); Markell, supra note 24, at 346 ("In short, the Court seems to use lenity not for its embodiment of due process and structural concerns, but as a tie-breaker for tough issues."); see also John G. Malcolm, Hook, Line \& Sinker: Supreme Court Holds (Barely) That SarbanesOxley's Anti-Shredding Statute Doesn't Apply to Fish, 2014-2015 Cato Sup. Cт. Rev. 227, 237 (2014) (describing the rule as a "tie-breaker and a rule of constitutional avoidance"); Orin S. Kerr, A Rule of Lenity for National Security Surveillance Law, 100 VA. L. Rev. 1513, 1533, 1535 (2014) ("the rule of lenity breaks the tie in favor of the individual instead of the State." and "The tiebreaker should go to the individual, not the State.").

104 As stated in the text, it is now conventional wisdom in the Supreme Court that lenity ranks after other interpretative methods, as a sort of "tiebreaker". See Callanan v. United States, 364 U.S. 587, 596 (1961) ("The rule comes into operation at the end of the process of construing what Congress has expressed, not at the beginning"); Moskal v. United States, 498 U.S. 103, 108 (1990) ("we have always reserved lenity for those situations in which a reasonable doubt persists about a statute's intended scope even after resort to 'the language and structure, legislative history, and motivating policies' of the statute." emphasis and citation omitted); compare the position of Justice Scalia and Chief Justice Roberts, who would rank lenity higher in the interpretative hierarchy. See id. at 132 (Scalia, J., dissenting) ("If the rule of lenity means anything, it means that the Court ought not . . . use an ill-defined general purpose to override an unquestionably clear term of art"); United States v. Hayes, 555 U.S. 415, 436-37 (2009) (Roberts, C.J., dissenting) (asserting that the rule should be applied prior to resort to legislative history: "If the rule of lenity means anything, it is that an individual should not go to jail for failing to conduct a 50-state survey or comb through obscure legislative history. Ten years in jail is too much to hinge on the will-o'-wisp of statutory meaning pursued by the majority.").

105 A more in depth discussion of the potential constitutional foundations for the American rule can be found in Julian R. Murphy, Lenity and the Constitution: Could Congress Abrogate the Rule of Lenity?, 56 HARV. J. ON LeGIS. 423 (2019).

106 United States v. Wiltberger, 18 U.S. (5 Wheat.) 76, 95 (1820). 


\section{(i) Separation of powers}

With the words "vested in the legislative", one sees a clear reliance on the separation of powers doctrine and an unwillingness on the part of the federal judiciary to venture into Congress' sovereign domain of criminal lawmaking. ${ }^{107}$ Astute scholars ${ }^{108}$ have noted the sub silentio harmonies between Wiltberger and the Court's seminal decision of eight years earlier, United States v Hudson \& Goodwin. ${ }^{109}$ In Hudson $\&$ Goodwin, it was held that federal courts had no power to develop a body of federal criminal common law. The Court in Hudson \& Goodwin recognized that "[t]he legislative authority of the Union must first make an act a crime ... [and] affix a punishment to it" before a federal court could enforce that punishment. ${ }^{110}$ Dan Kahan has suggested that, in Wiltberger, Chief Justice Marshall's proclamation that "the power of punishment is vested in the legislative ... department" 111 was a direct reference to the earlier words used in Hudson \& Goodwin. ${ }^{112}$ Kahan draws a further link between Wiltberger and Hudson \& Goodwin. In Wiltberger, the Court rejected the idea that crimes not clearly caught by the text of a criminal statute can nevertheless be brought within its ambit if they are "of equal atrocity, or of kindred character, with those which are enumerated". ${ }^{113}$ Kahan plausibly sees in this statement a rejection of the "mainstay of common law adjudication", analogical reasoning. ${ }^{114}$

Even without accepting Kahan's claims about the specific connections between Wiltberger and Hudson \& Goodwin, it is undeniable that the Court in Wiltberger saw the rule to be giving effect to the constitutional separation of powers. Unsurprisingly, subsequent decisions of the Supreme Court have similarly

107 See, generally, John Calvin Jeffries, Legality, Vagueness, and the Construction of Penal Statutes, 71 VA. L. Rev. 189, 202 (1985) ("As the branch most directly accountable to the people, only the legislature could validate the surrender of individual freedom necessary to the formation of the social contract. The legislature, therefore, was the only legitimate institution for enforcing societal judgments through the penal law." citation omitted); Akhil Reed Amar, America's Unwritten Constitution: The Precedents AND PRINCIPLes We Live By 427 (2012) ("Structurally, this rule has guaranteed that no person may be sent to the gallows or to prison unless both houses of Congress - and especially members of the lower house, the one most directly accountable to the people - have specifically authorized this grave intrusion upon bodily liberty.").

108 See, e.g., Kahan, supra note 14, at 359-61; Markell, supra note 24, at 339 n.27; Price, supra note 100 , at $898,909$.

109 United States v. Hudson \& Goodwin, 111 U.S. (7 Cranch) 32 (1812).

$110 \quad I d$. at 34.

111 United States v. Wiltberger, 18 U.S. (5 Wheat.) 76, 94 (1820). See also at 105 ("We can conceive no reason why other crimes, which are not comprehended by this act should not be punished. But congress has not made them punishable, and this court cannot enlarge the statute.")

112 Kahan, supra note 14, at 359.

113 Wiltberger, 18 U.S. (5 Wheat.) at 96 (emphasis added).

114 Kahan, supra note 14, at 361 (referring to Cass R. Sunstein, On Analogical Reasoning, 106 Harv. L. Rev. 741, 754 (1993)). See also Guido Calabresi, A Common LaW for the Age of Statutes (1985) (accepting that a statutory interpretation method that "updates" statutory text is, at its root, a common law method); Roscoe Pound, Common Law and Legislation, 21 HaRv. L. Rev. 383, 388, 388 n.6 (1908) (describing analogical statutory reasoning as being a common law method as old as Roman law). 
claimed to be effectuating the separation of powers by application of the rule. ${ }^{115}$ For example, in United States v. Bass, the Court wrote:

\begin{abstract}
"because of the seriousness of criminal penalties, and because criminal punishment usually represents the moral condemnation of the community, legislatures and not courts should define criminal activity ... Thus, where there is ambiguity in a criminal statute, doubts are resolved in favour of the defendant." 116
\end{abstract}

\title{
(ii) Due process
}

Today, the rule is commonly understood to be grounded in a second constitutional imperative-Due Process. ${ }^{117}$ More specifically, the rule is said to arise from the idea inherent in Due Process that a person ought to have sufficient notice, or fair warning, of the acts that a government would criminalize. ${ }^{118}$ At least two scholars ${ }^{119}$ have suggested that the Due Process foundation of the rule was present in Wiltberger in Chief Justice Marshall's gesture to "the tenderness of the law for the rights of individuals". Others have pointed to other early decisions, many of them by federal judges riding circuit. ${ }^{120}$ It is more convenient, for present purposes,

115 See, e.g., Whalen v. United States, 455 U.S. 684, 689 (1980) ("the power to define criminal offenses ... resides wholly with Congress"); Dowling v. United States, 473 U.S. 207, 213 (1985) ('Federal crimes, of course, 'are solely creatures of statute.' ... Due respect for the prerogatives of Congress in defining federal crimes prompts restraint in this area, where we typically find a 'narrow interpretation' appropriate." citations omitted); United States v. Aguilar, 515 U.S. 593, 600 (1995) ("We have traditionally exercised restraint in assessing the reach of a federal criminal statute ... out of deference to the prerogatives of Congress"); United States v. Lanier, 520 U.S. 259, 265 n.5, 267 n.6 (1997) ("The fair warning requirement also reflects the deference due to the legislature, which possesses the power to define crimes and their punishment." and "Federal crimes are defined by Congress, not the courts").

116 United States v. Bass, 404 U.S. 336, 348 (1971).

117 See, e.g., Cass Sunstein, Interpreting Statutes in the Regulatory States, 103 Harv. L. REv. 405, 471 (1989); William Eskridge, Public Values in Statutory Interpretation, 137 U. PA. L. Rev. 1007, 1029-30 (1989); David L. Shapiro, Continuity and Change in Statutory Interpretation, 67 N.Y.U. L. Rev. 921, 935-36 (1992); Jeffrey A. Love, Fair Notice About Fair Notice, 121 Yale L.J. 2395, 2400 (2011); John F. Manning, Clear Statement Rules and the Constitution, 110 Colum. L. Rev. 399, 406 n.26 (2010); Trevor Morrison, Fair Warning and the Retroactive Judicial Expansion of Federal Criminal Statutes, 74 S. CAL. L. REv. 455, 455 (2001); Nicholas Quinn Rosenkranz, Federal Rules of Statutory Interpretation, 115 Harv. L. Rev. 2085, 2094 (2002); Antonin Scalia, Assorted Canards of Contemporary Legal Analysis, 40 CASE W. RES. L. Rev. 581, 582 (1989).

118 See Connally v. General Construction Co., 269 U.S. 385, 391 (1926) (describing notice as "the first essential of due process of law").

119 Markell, supra note 24, at 339; Davies, supra note 86, at 1179.

120 For early invocations of a Due Process type justification for the rule see United States v. Wilson, 28 F. Cas. 699, 709 (C.C.E.D. Pa. 1830) (No. 16,730) (opinion of Baldwin, J.) ("[The rule] is founded on the tenderness of the law for the rights of individual ...."); United States v. Mann, 26 F. Cas. 1153, 1157 (C.C.D.N.H. 1812) (No. 15,718) (opinion of Story, J.); The Enterprise, 8 F. Cas. 732,734 (C.C.D.N.Y. 1810) (No. 4499) (opinion of Livingston, J.) ("It should be a principle of every criminal code, and certainly belongs to ours, that no person be adjudged guilty of an offence unless it be created 
to look one hundred years later to the 1931 decision of McBoyle v United States ${ }^{121}$ for an explicit invocation of the notice/fair warning language.

In McBoyle, the Supreme Court had to determine whether the National Motor Vehicle Theft Act $^{122}$ applied to airplanes. The text of the Act limited its application to "motor vehicles", which it defined as "any ... self-propelled vehicle not designed for running on rails." 123 While conceding that it was "etymologically ... possible" to read the definition inclusive of airplanes, Justice Holmes felt that the penal nature of the law required a narrower reading. Writing for the Court, Justice Holmes based this conclusion on the notice rationale:

\begin{abstract}
"it is reasonable that fair warning should be given to the world in language that the common world will understand, of what the law intends to do if a certain line is passed. To make the warning fair, so far as possible the line should be clear." 124
\end{abstract}

Since McBoyle, the Supreme Court has become increasingly explicit in espousing the due process basis of the rule. So, for example, in Dunn v United States the Court explained that the rule "reflects not merely a convenient maxim of statutory construction," but rather "is rooted in fundamental principles of due process which mandate that no individual be forced to speculate, at peril of indictment, whether his conduct is prohibited". ${ }^{125}$ Similarly, in United States $v$ Lanier, it was said that the rule "ensures fair warning by so resolving ambiguity in a criminal statute as to apply it only to conduct clearly covered."126

\title{
(iii) Federalism
}

The final constitutional dimension to the rule of lenity is, arguably, the effect it gives to values of federalism. On this account, federal criminal laws ought to be interpreted strictly so as to limit the scope of federal legislative incursion into regulatory realms traditionally left to the states. Kahan articulates the values underlying this reasoning in the following terms:

\footnotetext{
"What conduct a state chooses to criminalize and how severely it chooses to punish it are matters critical to the experience of deliberative democracy within that state. Because federal criminal law dictates uniform, national answers to such questions, expansive readings of federal criminal law threaten to extinguish the opportunity that states have to use criminal law to express and shape local ideals." 27
}

and promulgated in terms which leave no reasonable doubt of their meaning.") See, generally, Barrett, supra note 3, at 129-30.

121 McBoyle v. United States, 283 U.S. 25 (1931).

12241 Stat 324 (1919).

12341 Stat 324 (1919) § 2(a).

124 McBoyle v. United States, 283 U.S. 25, 27 (1931).

125 Dunn v. United States, 442 U.S. 100, 112 (1979).

126 United States v. Lanier, 520 U.S. 259, 266 (1997).

127 Kahan, supra note 14, at 421. 
This idea only rarely finds expression in the case law ${ }^{128}$ and, accordingly, has not garnered much academic attention. ${ }^{129}$ One reason that the federalism rationale for the rule is rarely relied upon independently of its other constitutional bases is that there is little to distinguish a federalism-focused application of the rule of lenity from the distinct interpretative canon of deference to states' rights. ${ }^{130}$ When applied to federal Congress' criminal lawmaking power the two rules are coextensive both requiring a narrow reading of federal criminal laws.

\section{STATUTORY MODIFICATION}

Just as the rule has arguably been impacted by statutory innovations in Australia so too have legislative enactments in the United States proved troubling for courts applying the rule and scholars theorizing it. At least two states have legislated to codify the rule: Florida and Ohio. ${ }^{131}$ The vast majority, however, have done the opposite - attempting to displace the rule by statute. This started in the early 1800s, when Tennessee and Virginia gaming laws required courts to interpret them "remedially", despite their penal character. ${ }^{132}$ The first generally applicable statutory provision purporting to displace the rule came into effect in Arkansas in $1838 .{ }^{133}$ In Livingston Hall's invaluable survey of the rule's early legislative modification he describes how other states soon followed suit at the recommendation of "commissioners appointed to revise the penal codes of the older states, or draft new ones for territories on their admission to statehood". ${ }^{134}$ In 1864 such a rule was proposed in New York where Field, Noyes and Bradford's Draft of a Penal Code for the State of New York (1864) included the following at $\S 10$ :

"The rule of the common law that penal statutes are to be strictly construed according to the fair import of their terms, has no application to this Code.

128 See the survey of Rehnquist-court era cases in Note, The New Rule of Lenity, 119 Harv. L. Rev. 2420, 2430-31 (2005).

129 Exceptions include John J. O'Connor, McNally v. United States: Intangible Rights Mail Fraud Declared a Dead Letter, 37 CATH. U. L. Rev. 851, 869 n.180 (1988); Id. at 23031; Julian R. Murphy, A Tale of Two Canons: Can a Federalism Canon Succeed where Lenity has Failed to Limit Federal Criminal Laws? VA. J. CRIM. L. (forthcoming).

130 There is some variance in the literature as to whether the methods of statutory interpretation that take account of federalism ought to be described as one canon or a set of canons. Compare SCALIA \& GARNER, supra note 32, at 290-94 (describing the "presumption against federal preemption canon") with William N. ESKRIDGE JR., PHILIP P. Frickey \& Elizabeth Garrett, Legislation and Statutory Interpretation $367-$ 75 (2006). (describing a number of related "substantive canons designed to protect state authority from federal encroachment").

131 Fla. Stat. \$775.021 (West 2000) ("The provisions of this code and offenses defined by other statutes shall be strictly construed; when the language is susceptible of differing constructions, it shall be construed most favorably to the accused."); Ohio Rev. Code Ann. § 2901.04(a) (Anderson 2002) ("sections of the Revised Code defining offenses or penalties shall be strictly construed against the state, and liberally construed in favor of the accused.")

132 See Hall, supra note 3, at 752-53 n.22 (listing relevant Tennessee and Virginia gaming law provisions and subsequent case law interpreting them).

133 Ark. Rev. Stat. (1837) c. 129, §§ 22-23 (approved March 5, 1838).

134 Hall, supra note 3, at 753. 
All its provisions are to be construed according to the fair import of their terms, with a view to effect its objects and to promote justice."

Despite legislative prescriptions, the general trend amongst courts in the $19^{\text {th }}$ and early $20^{\text {th }}$ century was to summarily ignore these statutory stipulations. Writing in 1935, Hall claims that in New York "[t]he liberal construction statute has been more honoured in the breach than in the observance". ${ }^{135}$ The position does not appear to be much different today. Jeffrey Love has conducted the most recent reviewbuilding on the work of Zachary Price. ${ }^{136}$ Love concludes "most state supreme courts seem to be invoking lenity when it suits their fancy."137

In the federal context, there is no analog to the state purposive interpretation provisions. That is not to say that such a thing has not been contemplated. The American Law Institute's Model Penal Code excludes the Rule, providing: "when the language [of a Code provision] is susceptible of differing constructions it shall be interpreted to further the general purposes [of the Code] and the special purposes of the particular provision involved." 138 Whether such a wide-reaching prescription could garner sufficient congressional support to pass into law remains to be seen. Furthermore, there would likely be a challenge to the constitutional validity of such a law, given the Due Process and separation of powers concerns that the rule is said to embody. ${ }^{139}$

Although there has not yet been a federal effort to comprehensively displace the rule, there have been attempts at more targeted modification of the rule in particular contexts, such as racketeering and securities fraud. ${ }^{140}$ The most notable of these attempts is contained in the Racketeer-Influenced and Corrupt Organizations Act ("RICO"), which provides: "The provisions of this [statute] shall be liberally construed to effectuate its remedial purposes." 141 Although RICO contains both criminal and civil provisions the liberal construction clause does not, at least on its face, limit its application to the civil provisions of the statute. Nevertheless, some courts have been reluctant to explicitly apply the directive to RICO's penal provisions in a way that would completely override the rule of lenity ${ }^{142}$ (although

\footnotetext{
Id. at 755 n.39.

136 Price, supra note 100, at 901-06.

137 Love, supra note 117, at 2396.

138 Modern Penal Code, $\S 1.02(3)$. The drafters of the Model Penal Code decided to displace "[t]he ancient rule that penal law must be strictly construed, . . . because it unduly emphasized only one aspect of the problem".
}

139 See also Einer Elhauge, Preference-Eliciting Statutory Default Rules, 102 Colum. L. REv. 2162, 2205 (2002) ("Where a legislature does clearly enact an interpretative statute that aims to undermine the preference-eliciting function of a statutory canon like the rule of lenity, however, that type of opt-out arguable violates whatever constitutional clauses in the particular jurisdiction vests legislative authority in each generation's legislature and interpretative authority in the courts.")

140 See also Section 853(a) of the Continuing Criminal Enterprises Act 21 U.S.C. $§ 853$ (a) (1994) ("The provisions of this section shall be liberally construed to effectuate its remedial purposes.")

141 Pub L No 91-452, § 904(a), 84 Stat 947 (1970) (emphasis added).

142 See, e.g., United States v. Anderson, 626 F.2d 1358, 1369-70 (8th Cir. 1980) (choosing to apply the rule over the liberal construction clause); United States v. Grzywacz, 603 F.2d 682, 692 (7th Cir. 1979) (Swygert, J., dissenting) (doubting whether RICO's liberal construction provision was intended to apply to the provisions establishing criminal 
the courts are arguably applying the provision sub silentio, given the expansive interpretations adopted in some RICO decisions). ${ }^{143}$ For example, in United States $v$ McClendon a Federal District Court expressed the view that: "Congress' call for a liberal interpretation in order to effectuate the Act's 'remedial purposes' does not outweigh the Court's duty under the 'rule of lenity' to construe criminal statues strictly." 144 Less forcefully, but no less tellingly, the Supreme Court has explicitly disclaimed reliance on the liberal construction clause when interpreting RICO's penal provisions ${ }^{145}$ and has suggested that the rule can be accommodated in the statutory scheme. ${ }^{146}$ At least one scholar has suggested that for courts to apply RICO's liberal construction clause to its penal provisions would violate constitutional Due Process guarantees. ${ }^{147}$

\section{E. Summary of the CURRENT AMERICAN APPROACH}

Notwithstanding general agreement about the common law and constitutional foundations of the rule there is rarely agreement on the Supreme Court as to its application. One scholar has written that "The rule of lenity today has very little practical effect in decisions interpreting criminal statutes"148, another claims "Today, strict construction survives more as a makeweight for results that seem right on other grounds than as a consistent policy of statutory interpretation."149 Before he was elevated to the Supreme Court, Justice Kavanaugh admitted "I do not have a firm idea about how to handle the rule of lenity. Of course, the Supreme

liability). For courts willing to apply the liberal construction provision to RICO's penal provisions, see United States v. Noriega, 746 F. Supp. 1506, 1516-17 (S.D. Fla. 1990) (applying the liberal construction clause in interpreting certain of RICO's penal provisions to cover certain conduct engaged in abroad); United States v. Huber, 603 F.2d 387, 394 (2d Cir. 1979) (relying on the liberal construction clause to interpret the meaning of "enterprise" in $\S 1961(4)$ ).

143 David Kurzweil, Note, Criminal and Civil RICO: Traditional Canons of Statutory Interpretation and the Liberal Construction Clause, 30 Colum. J. \& Soc. Probs. 41, 42 (1996) ("Courts have willingly accepted Congress' mandate to apply RICO broadly").

144 United States v. McClendon, 712 F. Supp. 723, 729 (E.D. Ark. 1988).

145 United States v. Turkette, 452 U.S. 576, 587 (1981).

146 Sedima, S.P.R.L. v. Imrex Company, Inc., 473 U.S. 479, 491 n.10 (1985); Reves v. Ernst \& Young, 507 U.S. 170, 184 n.8 (1993).

147 Barry Tarlow, RICO Revisited, 17 GA. L. Rev. 291, 309 (1983) ("If the liberal construction clause is applicable to determine the scope of criminal liability under [RICO], the provisions is therefore unconstitutional."); Ellsworth A. Van Graafeiland, RICO and the Rule of Lenity, 9 N. ILL. U.L. Rev. 331, 331 (1989) ("[the liberal construction] clause cannot be applied constitutionally to RICO's criminal provisions."). See also Alan R. Romero, Interpretative Directions in Statutes, 31 HaRv. J. on LegIS. 211, 229-30 (1994) (suggesting that constitutionally-grounded canons must take precedence over liberal construction provisions). Compare Donald Lee, The Availability of Equitable Relief in Civil Causes of Action in RICO, 59 Notre Dame L. Rev. 945, 951 (1984) ("due process does not require the strict construction of penal statutes.") with Craig W. Palm, RICO and the Liberal Construction Clause, 66 Cornell L. Rev. 167, 182, 182 n.54 (1980) (“The Supreme Court has never held that strict construction of penal statutes is constitutionally compelled." And "[decisions of the Supreme Court suggest] that the strict construction rule is prudential rather than mandatory.")

148 Price, supra note 100 , at 899.

149 Jeffries, supra note 107, at 198-99. 
Court seems to be very uncertain about the rule of lenity, too." 150 Yet the Court continues to refer to the rule and purport to apply it. ${ }^{151}$ If application of the rule appears "random" 152 that is likely because of the diversification of interpretative tools and methodologies now in use. ${ }^{153}$ This is not a problem unique to the rule. In a thorough survey of the Supreme Court's approach to statutory interpretation, one scholar summarized the approach as "eclectic". ${ }^{154}$ While the rule has been subjected to sustained academic criticism - including some prominent voices calling for its abolishment ${ }^{155}$ - there has never been serious doubt in the Supreme Court that the tiebreaker version of the rule is sound. Recent cases suggest as much, with the rule dictating the result for a closely split Court in Yates. ${ }^{156}$

\section{Similarities, Differences and AtTEMPts at Explanation}

\section{A. EARLY CASE LAW}

As has been seen, early statements of the rule in Australia and the United States both gave it real force as a tool engaged in the face of any textual ambiguity in penal statutes. On both of these accounts, textual ambiguity could not easily be resolved by reference to the overarching purpose of the statute. Instead, both accounts stressed the need for clarity in the words of criminal statutes and thought it proper to apply the rule in the absence of such textual clarity. In Australia, that initial position was complicated by the persuasive reasoning of Justice Isaacs' dissent in Cawsey (whereas there was no dissent in the American Wiltberger decision). The chronological distinction between Cawsey and Wiltberger is also relevant. Cawsey was decided one hundred years after Wiltberger, by which time the more expansive approach to statutory interpretation that was heralded in America by the Church of the Holy Trinity decision was also starting to make its way into Australian courts. Indeed, it is instructive to note that Justice Isaacs relied on American authority in his dissent in Cawsey - thus demonstrating the influence that the enlightenment in American statutory interpretation eventually came to have on Australia's approach to penal statutes.

150 Kavanaugh, supra note 27, at 2145 n.136.

151 Note, The New Rule of Lenity, 119 Harv. L. Rev. 2420, 2421 (2005) (conducting a comprehensive review of the Rehnquist Court's application of the rule of lenity and concluding: "lenity is not defunct. In a small but significant number of cases, the Court applied the rule to reach results that cannot plausibly be explained on other grounds.")

152 Eskridge, supra note 117, at 1083.

153 See Solan, supra note 81, at 102-08 (documenting the diversification of statutory interpretation methods at the Supreme Court).

154 Nicholas S. Zeppos, The Use of Authority in Statutory Interpretation, 70 Tex. L. Rev. 1073, 1120 (1992). See also Easterbrook, supra note 27, at 81-82 (“A conference about 'best practices' for legal inquiry supposes that there are practices. In the field of legal interpretation, that assumption is doubtful").

155 See, e.g., Hall, supra note 3, at 768-70; John Barker Waite, The Criminal Law in ACTION 320 (1934); Jeffries, supra note 107, at 219-20; Kahan, supra note 14, at 396.

156 Yates v. United States, 135 S. Ct. 1074 (2015). 


\section{B. CONSTITUTIONAL FoundaTIONS}

Perhaps the starkest difference in the rule's development in Australia and the United States is that only in the latter country has the rule gained a constitutional foothold. The first, and most obvious, reason for this difference is that Australia's Constitution contains no provision comparable to the Due Process clauses contained in the Fifth and Fourteenth Amendments to the United States Constitution. ${ }^{157}$ Less easy to explain is the failure of Australian courts to conceive of the rule as an expression of the separation of powers. It is true that Justice O'Connor in Cawsey did use separation of powers language to justify a strict interpretation of the penal provision at issue, but the other Justices of the Court (and most courts since) have seen the rule as a common law interpretative canon rather than a constitutional requirement. Similarly, to this author's knowledge, no Australian court has applied the rule to protect State sovereignty in the Australian federal structure. This is likely due to the attenuated species of federalism that now prevails in Australia's constitutional system; a system characterized by "the High Court's reluctance to develop a constitutional jurisprudence of federalism that might seriously temper" the post-1920 phenomenon of "the steady expansion of the powers of the national government to the diminishment of those of the states". ${ }^{158}$

In contrast, the rule has been expressed in constitutional terms in the United States for close to two centuries - primarily in furtherance of separation of powers and Due Process values, but also, occasionally, for federalism-orientated reasons. Nevertheless, there is no agreement amongst the academy as to whether the rule is merely constitutionally inspired or whether it is in fact a constitutional requirement. So, for example, Ross Davies calls the rule a "quasi-constitutional norm" as distinct from a "truly constitutional standard". ${ }^{159}$ Einer Elhauge describes the constitutional foundations of the rule as "dubious". ${ }^{160}$ This analysis would seem to be borne out by the fact that the rule has been subject to legislative displacement in many of the states. ${ }^{161}$

157 It should be noted, however, that the lack of an explicit due process clause in the Australian constitution has not precluded the Courts from protecting certain due process rights. See, generally, Anthony Gray, Criminal Due Process and Chapter III of THE Australian Constitution (2016); Will Bateman, Procedural Due Process under the Australian Constitution, 31 Syd. L. Rev. 32 (2009).

158 Shipra Chordia \& Andrew Lynch, Federalism in Australian Constitutional Interpretation: Signs of Reinvigoration?, 33 UnIv. of QueEnsL. L. J. 83, 83 (2014). See, generally, Stephen Gageler, Beyond the Text: A Vision of the Structure and Function of the Constitution, 14 J. OF THE N.S.W. B. Ass'N. 30 (2009). For an informative comparison of federalism in the United States and Australia (as well as other countries), see MichaEL Burgess, Comparative Federalism: Theory and Practice (2006).

159 Davies, supra note 86, at 1175, 1195-96 n.92.

160 Elhauge, supra note 139, at 2196.

${ }_{161}$ Although one could argue that due process and separation of powers principles might afford more law-making latitude to state courts than federal courts given that state courts are charged with the development of common law crimes whereas federal courts are precluded from doing so (United States v. Hudson \& Goodwin, 111 U.S. (7 Cranch) 32 (1812)). 


\section{StatuTory Modification}

There is significant diversity of approach to the rule amongst Australia's state and federal legislatures, just as there is in the United States. Two Australian states have legislated to preserve the rule, ${ }^{162}$ while at least two American states have enshrined the rule in their own statutory provisions. ${ }^{163}$ At the federal level, Australia has an overarching liberal construction clause while the United States Congress has preferred to enact targeted liberal construction clauses within specific pieces of penal legislation, like RICO. It is possible to make two general observations about legislative modification of the rule in Australia and the United States. First, notwithstanding the constitutional foundations of the rule in the United States, the rule appears to be vulnerable to legislative displacement in both countries. Secondly, where legislative enactments purport to erode the rule of lenity, courts will only reluctantly give them that effect. In summary, then, the diversity of approaches as amongst Australian and American courts and legislatures to the legislative displacement of the rule of lenity is an example of what Abbe Gluck has called state "laboratories of statutory interpretation". ${ }^{164}$

\section{Contemporary Iterations of the RULE}

Finally, it is surprising to note that the current versions of the rule in Australia and the United States share very much in common despite their distinct routes of historical development. Both countries have grappled with the application of the rule to hybrid civil-criminal statutes; both countries have struggled to identify the precise degree of "ambiguity" or "doubt" required to engage the rule; and both countries have placed the rule last in the interpretative hierarchy - as a "last resort" 165 in Australia and a "tiebreaker" in the United States.

\section{CONCLUSION}

This article has sought to survey the genesis and development of the rule of lenity (or the rule that ambiguous penal laws be interpreted in favor of the subject) in Australia and the United States. This descriptive analysis has revealed some significant doctrinal differences in each country's development of the rule, primarily deriving from local constitutional differences. In the knowledge of these differences, it is surprising to see how closely the two countries' contemporary versions of the rule align - the United States using the language of "tie-breaker" and Australia using the language of "last resort." These linguistically similar formulations have been arrived at despite very little modern reference to decisions

162 Queensland and South Australia, see Acts Interpretation Act $§ 141954$ (Qld.); Acts Interpretation Act $§ 221915$ (S. Austl.).

163 Price, supra note 100, at 902 n. 110.

164 Abbe R. Gluck, The States as Laboratories of Statutory Interpretation, 119 YaLE L. J. 1750,1790 (2010).

165 The American rule of lenity has also been described as "a canon of last resort". See Mark S Popofsky, The Section 2 Debate: Should Lenity Play a Role?, 7 Rutgers Bus. L.J. 1, 5 (2010). 
of the other country's case law. The question left unanswered by this analysis is, of course, the most interesting. Why is it that the rule has achieved such a similar state in both countries despite the local differences? The answer to this question is best left for future research. 